\title{
Experimental model for graft -versus-host disease in rat limb allotransplantation $^{1}$
}

Lydia Masako Ferreira²

Ferreira LM. Experimental model for graft-versus-host disease in rat limb allotransplantation. Acta Cir Bras [serial online] 2004 Vol 19 Special Edition. Available on URL: http://www.scielo.br/acb.

\begin{abstract}
Graft versus-host disease (GVHD) is a potentially fatal immune-regulated injury occurring unpredictably in solid organ and bone marrow transplant recipients. This model attempts the incidence of potentially lethal GVHD in limb transplants. Two inbred rat strains ACI and Lewis with a strong major and minor histocompatibility locus mismatch were studied. The perspectives of this model are study the incidence of GVHD in limb transplant, determine the best model for the study of the GVHD in limb transplant and prevention and treatment concerning the GVHD.
\end{abstract}

KEY WORDS - Graft versus host disease. Limb transplantation. Allotransplantation. Microsurgery, Method.

\section{Introduction}

Graft versus-host disease (GVHD) is a potentially fatal immune-regulated injury occurring unpredictably in solid organ and bone marrow transplant recipients. Simply put, in GVHD, the transplanted lymphocytes within the donor organ recognize the recipient's tissue as foreign and set to destroy it.

GVHD may be acute or chronic, with cutaneous, gastrointestinal, pulmonary and a hepatic manifestations. It can be fatal and no regimen has yet been completely satisfactory in preventing or treating it. While GVHD is acknowledged as a possible event after life-saving organ transplantation, it is not known whether it will develop after elective limb transplantation ${ }^{1}$.

Limbs clearly have greater amounts of lymphoid tissue, which may incite GVHD and thus limb transplant recipients would seem to be at great risk for GVHD².

The role of immunosuppressants in GVHD is unclear. On one hand, immunosuppression would seem to prevent GVHD by decreasing the immune response of the lymphocytes within the transplants. Alternatively, immunosuppression may actually worsen GVHD be decreasing the recipient's ability to counter the deleterious effects.

\section{Proposition}

This model attempts the incidence of potentially lethal GVHD in limb transplants. 


\section{Method Description}

All rats were males at 16-22 weeks of age, with an average of 300 grams.

Two inbred rat strains ACI and Lewis with a strong major and minor histocompatibility locus mismatch were studied. When these rats are crossed, the hybrid (F1) generation is genetically ACI-L (FIGURE 1).

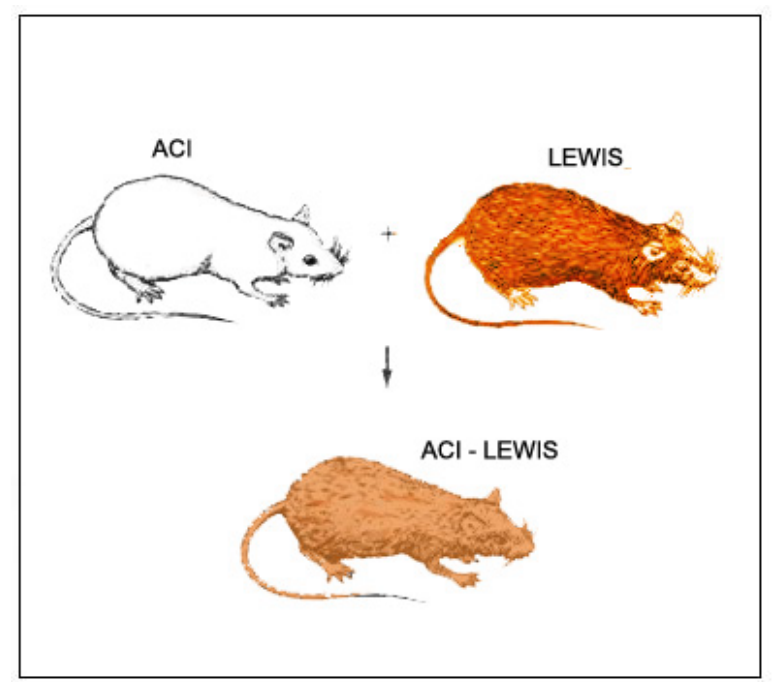

FIGURE 1 - Hybrid (F1) generation is genetically ACI-L by ACI and Lewis (L) corring.

These rats do not recognize a limb from either an ACI or L rat as foreign. Therefore, when either an ACI or L limb is transplanted to these F1 (ACI-L) animals, there is no rejection (FIGURE 2). However, the transplanted ACI or L limb recognizes a portion of the F1 (ACI-L) animal as foreign, thus potentially instigating GVHD.

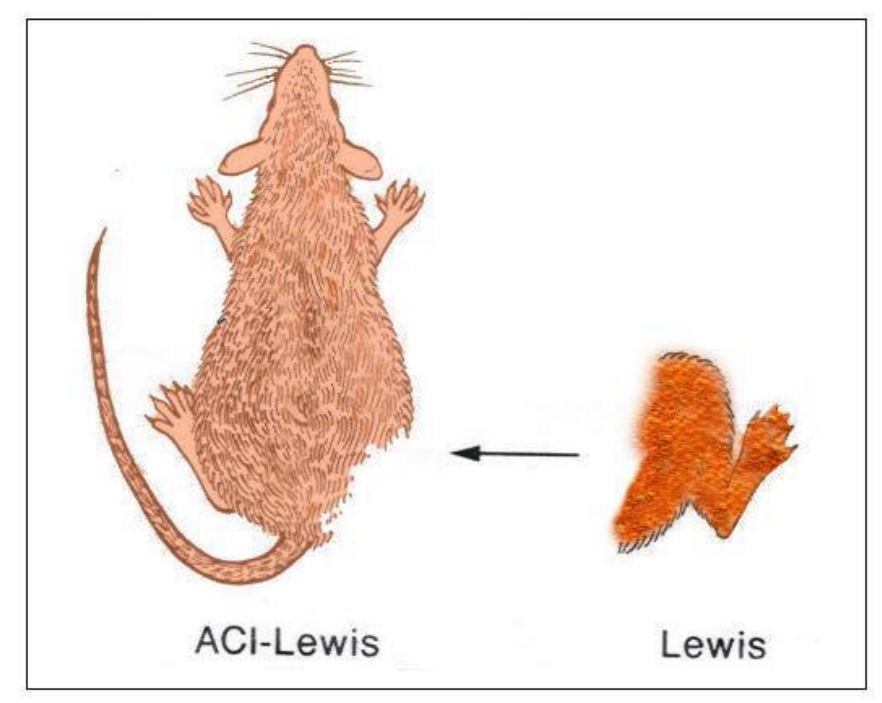

FIGURE 2 - Lewis limb is transplanted to these F1 (ACI-L) animals. 
ACI-L rats were used as recipient and Lewis rats were used as hindlimb allografts donors. Sodium pentobarbital at a dose of $50 \mathrm{mg} / \mathrm{kg}$ intraperitoneal was administered for anesthesia. Limbs were amputed at midfemur level on both ACI-L and L rats, with orthotopic transfer of the L limb to the corresponding ACI-L recipient site ${ }^{3,4}$.

Bone fixation was achieved using a gauge needle as an intramedullary rod. The muscle was approximated using 4-0 nylon. The sciatic nerve, femoral artery and vein were repaired primarily with interrupted 10-0 nylon sutures using standard microsurgical technique. The skin was sutured with uninterrupted 4-0 nylon ${ }^{3,4}$.

A protective wire mesh collar was placed around the proximal thigh to prevent authophagia of the insensate limb.

Daily: weight, visual exam of the animal for limb vascularity, clinical signs of GVHD (ear erythema, footpad hyperkeratosis, dermatitis, weight loss, unkempt appearance, diarrhea); ear skin biopsy was done at POD 21, on five weeks and one each month ${ }^{3,4}$. GVHD) $)^{5}$

At sacrifice: biopsy of skin, tongue, liver, small bowel and limb muscle (assess for

\section{Perspectives}

1. Incidence of GVHD in limb transplant ${ }^{6}$.

2. Determine the best model for the study of the GVHD in limb transplant ${ }^{7}$.

3. Prevention and treatment concerning the $\mathrm{GVHD}^{8}$.

\section{References}

1. Ferreira LM, Benhaim P, Anthony JP, Borsanyi JP, Mathes SJ, Andrews JM - Síndrome Enxerto versus Hospedeiro: uma possibilidade em transplante homólogo de membro Acta Orthop Bras. 1994;2(2):63-6.

2. Ferreira LM, Borsanyi JP, Benhaim P, Anthony JP, Mathes S - Rat limb allotransplantation: Risk for Graft-versus-Host Disease. World J Plast Aesth and Reconstr Surg. 1999; 3(1):108-11.

3. Ferreira LM, Borsanyi JP, Benhaim P, Anthony JP, Mathes S - Sinergic effect of subtherapeutic dose combination immunotherapy with cyclosporine and RS-61443 in rat limb allotransplantation. World J Plast Aesth and Reconstr Surg. 1999;3(1):108-11.

4. Ferreira, LM - Transplantes Homólogos de Membro In: Ferreira, LM Manual de Cirurgia Plástica, Editora Atheneu, São Paulo cap. 22, P 261-4, 1995.

5. Saurat JH, Gluckman E, Bussel A - The lichen planuslike eruption after bone marrow transplantation. Br J Dermatol. 1975; 93:675-81.

6. Ferreira LM, Anthony JP, Mathes J, Andrews JM, Laredo Filho J - Complicações em transplante alógeno microcirúrgico de membro (tecido composto), em ratos. Rev Assoc Med Bras. 1995; 41(3):213-8.

7. Ferreira LM, Ferreira LRK - Experimental model: historic and conceptual revision. Acta Cir Bras. 2003;18(sp):1-3.

8. Ferreira LM, Andrews J, Laredo Filho J - Transplante homólogo de membro (tecido composto). Perspectivas para o futuro. Rev Assoc Med Bras. 1995; 41(2):151-7. 
Ferreira LM. Modelo experimental para síndrome enxerto versus hospedeiro em transplante de membro. Acta Cir Bras [serial online] 2004 Vol 19 Edição Especial. Disponível em URL: http://www.scielo.br/acb.

RESUMO - A Síndrome Enxerto versus Hospedeiro (SEVH) é uma condição imune potencialmente fatal que ocorre quando linfócitos transplantados do órgão doador reconhecem como estranho o tecido do receptor e tenta destruí-lo. Este modelo tem como objetivo verificar a incidência de SEVH em transplantes alógenos de membro. Duas espécies, ratos ACI e Lewis, lócus de maior e menor histocompatibilidade, foram combinadas. Determinar a incidência da SEVH nos transplantes alógenos de membro; estudar a regeneração nervosa e a toxicidade das drogas imunosupressoras; determinar a prevenção e o tratamento desta síndrome.

DESCRITORES - Sindrome Enxerto versus Hospedeiro. Transplante alógeno. Transplante de tecidos. Microcirurgia.

Conflito de interesse: nenhum

Fonte de financiamento: $\mathrm{CNPq}$

Correspondence:

Lydia Masako Ferreira MD, PhD

Rua Napoleão de Barros, 715, $4^{\circ}$ andar

CEP: 04024-900 São Paulo - SP

Tel: (11)557604118 FAX: (11) 55716579

sandra.dcir@epm.br

lydia.dcir@epm.br 